\title{
KONTRIBUSI KEBUN PLASMA TERHADAP KEUNTUNGAN KEBUN NGABANG PT PERKEBUNAN NUSANTARA XIII (Persero)
}

\author{
Amran B Simbolon*, Erlinda Yurisinthae ${ }^{\star \star}$, Adi Suyatno** \\ *Mahasiswa MMA Fakultas Pertanian Universitas Tanjungpura Pontianak \\ ** Staf Pengajar Fakultas Pertanian Universitas Tanjungpura Pontianak
}

\begin{abstract}
The purpose Of this study is to know how much of Contribution plasma estate concerning to Profit Ngabang Estate of PTP Nusantara XIII (Persero). Methods of reserch conducted is case research. Case researach is commit direct relationship between variable accourding to cause effect. The methods that use in this research is common size. Its making over number in loss/Profit balance become percentage. Database that use in this reasearch from accounting report of PT Perkebunan Nusantara XIII (Persero) from 2007 to 2012 at Ngabang estate. Ngabang estate have $31,7 \%$ of plasma estate and $68,3 \%$ inti esatate. The age of palm oil estate with have average 29 years old. According result of research plasma estate have a negatif relation to profit of Ngabang esatate PT Perkebunan Nusantara XIII (Persero) with percentage $-161,91 \%$. Its cause some factor, first advantage of amortisasi, second low productivity of palm oil caused the age too old. Third, Prices of plam oil comodity lower with the result next year must be relationship between plasma estate and inti estate has been loss. Beside that have suggestion the palm oil must be replanted and formation of Private managemet in plasma estate.
\end{abstract}

Key Words : Contribution, Plasma, inti, Profit

\section{PENDAHULUAN}

Industri perkebunan kelapa sawit di Indonesia memiliki prospek yang sangat bagus jika dilihat dari keunggulan komoditi, banyaknya industri turunan (down stream industry) yang dihasilkan dan peraihan pasar dunia (market share) yang berkembang sampai dengan saat ini. Berdasarkan data Oilword (2010) dinyatakan bahwa negara Indonesia berkontribusi sebesar $47 \%$ terhadap produksi minyak sawit atau crude palm oil (CPO) dunia, sedangkan negara tetangga Malaysia berkontribusi sebesar 39\%. Data tersebut memberikan kesimpulan bahwa Indonesia merupakan negara terbesar pengekspor minyak kelapa sawit dunia yang dapat dinilai memiliki posisi tawar-menawar (bergaining power) lebih baik.

Tanaman Kelapa Sawit memiliki Manfaat dan Keunggulan, bagian yang paling utama untuk diolah dari kelapa sawit adalah buahnya. Bagian daging buah menghasilkan minyak kelapa sawit mentah yang diolah menjadi bahan baku minyak goreng. Kelebihan minyak nabati dari sawit adalah harga yang murah, rendah kolesterol, dan memiliki kandungan karoten tinggi. Minyak sawit juga dapat diolah menjadi bahan baku minyak alkohol, sabun, lilin, dan industri kosmetika. Sisa pengolahan buah sawit sangat potensial menjadi bahan campuran makanan ternak dan difermentasikan menjadi kompos. Tandan kosong dapat dimanfaatkan untuk mulsa tanaman kelapa sawit, sebagai bahan baku pembuatan pulp dan pelarut organik, dan tempurung kelapa sawit dapat dimanfaatkan sebagai bahan bakar dan pembuatan arang aktif.

PT Perkebunan Nusantara XIII (Persero) atau disebut PTPN XIII (Persero) sebagai salah satu Badan Usaha Milik Negara (BUMN) yang bergerak dalam bidang agroindustri komoditi perkebunan kelapa sawit. PTPN XIII (Persero) memiliki peranan yang strategis dalam mengembangkan bisnis pada sub sektor komoditi kelapa sawit dan karet. Peranan ini meliputi kontribusi ekonomi secara regional dan nasional melalui pendapatan Produk Domestik Bruto (PDB) dengan berbagai kontribusi langsung seperti 
penyerapan tenaga kerja, pembayaran deviden dan pajak kepada pemerintah, serta berbagai bentuk retribusi lainnya

Salah satu unit usaha di PTPN XIII (Persero) yang telah mengembangkan kemitraan usaha perkebunan dengan pola PIR adalah Kebun Ngabang yang terletak di Kabupaten Landak, Kalimantan Barat. Menurut data tahun 2009, kebun Ngabang telah berhasil membangun kemitraan ini dengan komposisi areal tanaman berkisar pada angka $31,7 \%$ kebun perusahaan Inti dan $68,3 \%$ atau merupakan kebun Plasma kebun inti luasnya 3.714 ha dan kebun plasma luasnya 7.998 ha.Kemitraan perkebunan kelapa sawit antara perusahaan inti dan plasma ini telah berjalan lebih dari 25 tahun, dan keduanya dapat memberikan keuntungan yang bermanfaat bagi siklus hidup baik bagi kelanjutan perusahaan maupun bagi ekonomi dan kesejahteraan masyarakat plasma. Produksi perhektar 10 tahun terakhir ini cukup bervariasi dari 9 ton/ha/tahun sampai dengan 17,9 ton/ha/tahun.Perjalanan waktu yang cukup panjang ini merupakan hubungan yang dapat dinilai bersifat berkelanjutan sehingga secara harfiah tentu hubungan ini dapat saling memberikan keuntungan.

Perkebunan inti dan plasma dilingkungan Kebun Ngabang PTPN XIII (Persero) yang memiliki komposisi untuk kebun inti hanya 31,7 \% merupakan hal yang tidak lazim. $\mathrm{Hal}$ ini dikarenakan berdasarkan peraturan menteri pertanian No.26/Permentan/OT.140/2/207 tentang perizinan usaha perkebunan bahwa perusahaan yang memiliki izin Usaha Perkebunan untuk budidaya (IUP-B) wajib membangun kebun untuk masyarakat (plasma) paling rendah 20\% luas areal kebun semestinya.

Hal yang menarik adalah apakah keberadaan kebun plasma sebesar $68,3 \%$ ini dapat memberikan kontribusi yang sebanding bagi keuntungan perusahan. Apabila dapat dipahami lebih dalam berkaitan manfaat ini, tentu saja kemitraan kebun inti-plasma dapat menjadi pola penggerak dinamika ekonomi daerah yang lebih besar dan bermanfaat lebih luas.

Penelitian ini nertujuan untuk mengetahui kontribusi plasma terhadap keuntungan Kebun Ngabang PT Perkebunan Nusantara XIII (Persero) .Kontribusi ini bukan saja berupa keuntungan finansial melainkan keuntungan-keuntungan lain bagi keberlanjutan kemitraan yang lebih baik.

\section{METODE PENELITIAN}

Penelitian ini dilakukan dengan metode studi kasus yang artinya penelitian dilakukan secara langsung ke dalam obyek penelitian (sebagai sumber data dan informasi) untuk mengetahui hubungan variabel-variabel yang lebih jelas dan penyebab terjadinya suatu sebab akibat

Lokasi penelitian terletak pada unit Kebun Ngabang PT Perkebunan Nusantara XIII (Persero) di Kabupaten Landak Provinsi Kalimantan Barat. Penelitian ini dilakukan dengan menganalisis data perusahaan (audited) enam tahun, sesuai laporan kinerja perusahaan tahunan (per 31 Desember tahun 2007 sampai dengan tahun 2012). Hal ini disebabkan kebijakan PT Perkebunan Nusantara XIII (Persero) mengenai data perusahaan yang sudah lewat enam tahun harus dimusnahkan. Sehingga hanya bisa menggunakan data enam tahun terakhir ini sebagai acuan dan gambaran

\section{ANALISIS DATA}

Untuk menganalisis tingkat kontribusi dalam hubungan kemitraan antara kebun inti dan plasma akan dilakukan Analisis common size. Analisis common Size yakni analisis yang dibuat dengan cara menghitung tiap - tiap rekening dalam laporan rugi laba dan neraca menjadi proporsi dari total penjualan ( untuk laporan rugi - laba) 
atau dari total aktiva untuk neraca ( Hanafi \& Halim,2007:70). Untuk analisa common size khususnya kinerja keuangan akan dibuat sesuai dengan kebutuhan dalam penelitian ini.

Analisis ini merubah angka-angka yang ada dalam Neraca dan Laporan Rugi Laba menjadi persentase berdasarkan dasar tertentu. Untuk angka-angka yang ada di Neraca, common basenya adalah total aktiva. Dengan kata lain, total aktiva dipergunakan sebagai $100 \%$. Untuk angka-angka yang ada dalam Rugi Laba, penjualan netto juga dipergunakan $100 \%$.

\section{HASIL DAN PEMBAHASAN}

\section{Analisis Common Size}

Hasil perhitungan kontribusi dengan menggunakan program excel dipaparkan pada gambar 1. Adapun rincian perhitungannya adalah sebagai berikut pada tabel 1 Rekapitulasi perhitungan rugi/laba dan kontribusi :

Tabel 1. Rekapitulasi perhitungan rugi/laba Kebun inti Plasma dan kontribusinya terhadap Kebun Ngabang

\begin{tabular}{cccccccc}
\hline & $\mathbf{2 0 0 7}$ & $\mathbf{2 0 0 8}$ & $\mathbf{2 0 0 9}$ & $\mathbf{2 0 1 0}$ & $\mathbf{2 0 1 1}$ & $\mathbf{2 0 1 2}$ & Rata-Rata \\
\hline $\begin{array}{c}\text { Rugi/laba } \\
\text { Inti }\end{array}$ & 39.667 .428 & 36.158 .035 & 29.074 .727 & 30.646 .450 & 24.717 .185 & 21.050 .178 & 30.219 .001 \\
$\begin{array}{c}\text { Rugi/laba } \\
\text { Plasma }\end{array}$ & $(4.830 .643)$ & $(4.773 .963)$ & 746.579 & 13.262 .648 & $(22.122 .876)$ & 95.925 .836 & 13.034 .597 \\
$\begin{array}{c}\text { Rugi/laba } \\
\text { Kebun } \\
\text { Ngabang }\end{array}$ & 53.260 .175 & 33.383 .673 & 29.173 .973 & 43.909 .096 & 2.594 .309 & $(74.875 .657)$ & 14.574 .262 \\
$\begin{array}{c}\text { Kontribusi } \\
\text { Plasma }\end{array}$ & $(9,07 \%)$ & $(14,30 \%)$ & $2,56 \%$ & $30,20 \%$ & $(852,75 \%)$ & $(128,11 \%)$ & $(161,91 \%)$ \\
$\begin{array}{c}\text { Kontribusi } \\
\text { Inti }\end{array}$ & $74,48 \%$ & $108,31 \%$ & $99,66 \%$ & $69,80 \%$ & $952,75 \%$ & $(28,11 \%)$ & $207,34 \%$ \\
\hline
\end{tabular}

Sumber Data: Analisis Data Sekunder, 2013

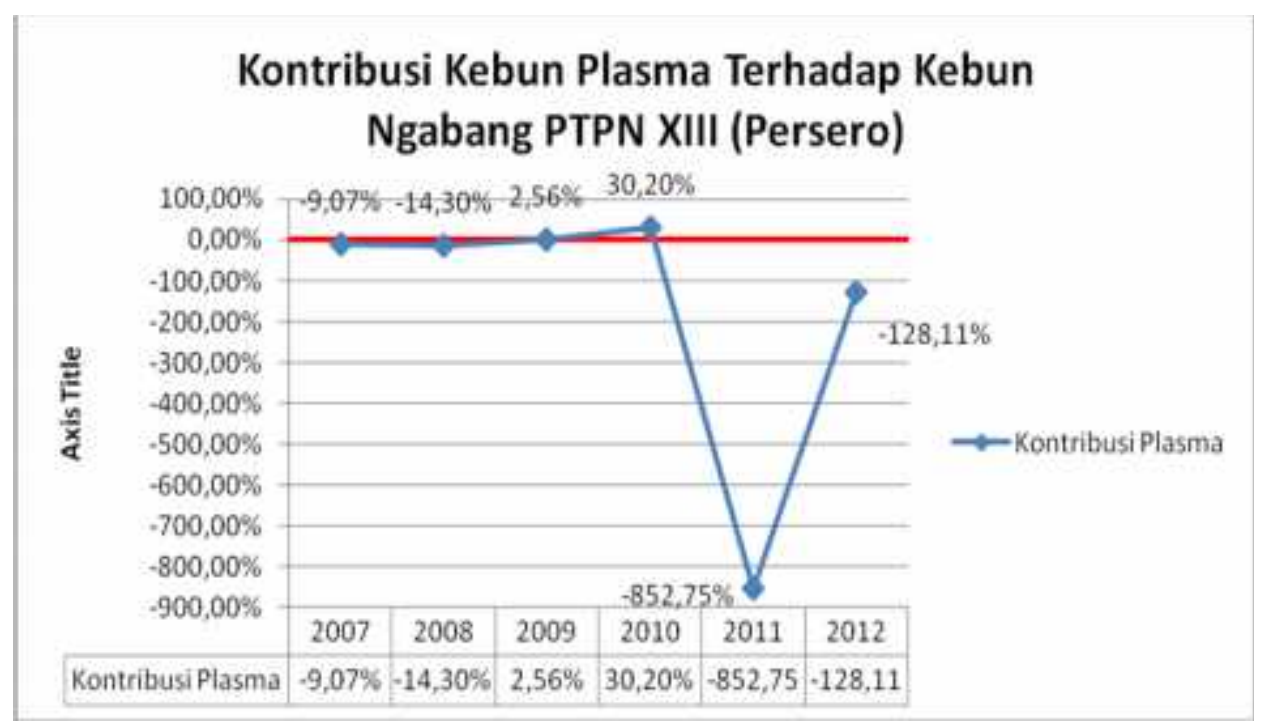

Gambar 1. Kontribusi Kebun Plasma 
Berdasarkan tabel 1 dan gambar 1 kontribusi kebun plasma terhadap keuntungan Kebun Ngabang PT Perkebunan Nusantara XIII (Persero) pada tahun 2007, 2008, 2011 dan 2012 negatip artinya perusahaan mengalami kerugian. Sebaliknya pada tahun 2009, 2010 positif artinya memberikan keuntungan. Sedangkan untuk nilai rata-rata kontribusi Kebun Plasma terhadap keuntungan Kebun Ngabang sebesar -161,91\%. Oleh karena itu dapat disimpulkan bahwa berdasarkan analisa common size dengan data yang penulis dapatkan 6 tahun terkahir mengindikasikan kebun plasma merugikan kebun Ngabang PT perkebunan Nusantara XIII (Persero). Dengan demikian perlu adanya evaluasi untuk segera melakukan peremajaan tanaman atau replanting (tanaman ulang) pada kebun plasma sehingga tidak membebani keuangan perusahaan khususnya di Kebun Ngabang. Apalagi hal ini ditambah proporsi luasan kebun plasma di kebun Ngabang sebesar $68,3 \%$ dengan luas 7.998 ha.

Berdasarkan penjelasan diatas dan analisa dilapangan, ada beberapa faktor yang menyebabkan Kontribusi Kebun Plasma terhadap Keuntungan Kebun Ngabang PT Perkebunan Nusantara XIII (persero) bernilai negatif. Faktor-faktor tersebut antara lain :

a. Produktivitasnya rendah

Produktivitas rendah dikarenakan umur tanaman sudah tua renda $\geq 24$ tahun. Selain itu juga pemupukan yang dilakukan petani plasma program $4 \mathrm{~T}$ (Tepat Jenis, Tepat Dosis,Tepat Waktu dan Tepat Cara) sulit untuk diimplikasikan pada kebun plasma. Hal ini dikarenakan petani menganggap bahwa tanpa dipupuk sesuai rekomendasipun tanaman kelapa sawit tetap berproduksi menghasilkan buah. Namun tanpa disadari oleh petani bahwa pengaruh pupuk akan mengurangi berat tandan dan jumlah tandan yang dihasilkan. Apabila harga pupuk mengalami kenaikan tidak jarang ada sebagian petani yang tidak memupuk tanaman kelapa sawitnya.

b. Petani sering memotong/memanen buah mentah yang mengakibatkan rendemen tidak sesuai RKAP (Rencana Kerja Anggaran Perusahaan).

Hal inilah yang terjadi dilapangan, dikarenakan perusahaan khusunya kebun Ngabang mengalami kerugian. Terget Rendemen yang dibuat dalam RKAP (Rencana kerja Anggaran Perusahaan) tidak tercapai. RKAP yang dibuat dan disusun merupakan suatu kebijakan yang ada di PT Perkebunan Nusantara XIII (persero) dan berlaku untuk semua unit. RKAP ini wajib hukumnya untuk dipatuhi karena merupakan gambaran kerja yang akan dicapai dalam waktu 1 tahun kedepan. Apabila hasilnya tidak sesuai, tentunya berpengaruh terhadap pos anggran biaya yang sudah diestimasikan.

c. Sebagian petani plasma ada yang menjual produksinya ke pihak luar.

Hal ini dilakukan untuk menghindari pemotongan kredit dan mendapatkan uang kontan. Sebagian petani merasa masih terbebani hutang yang terus terakumulasi oleh perusahaan akibat pembukaan kebun plasma di Kebun Ngabang PT Perkebunan Nusantara XIII (Persero). Manajemen kebun Ngabang dalam hal ini sudah mengupayakan kepada petani plasma untuk melakukan penyelesaian secara kekeluargaan dan menghimbau untuk tidak menjual buahnya keluar. Namun masih ada saja beberapa oknum petani tidak mengindahkannya.

d. Keluarnya SK gubernur tahun 2010 yang diberlakukan pada tahun 2011.

SK tersebut mengharuskan perusahaan membayar TBS petani kebun plasma sesuai harga TBS dengan rendemen $21,4 \%$, sementara rendemen saat produksi di pabrik tidak mencapai $21,4 \%$. Hal ini yang mengakibatkan selisih rendemen tersebut merupakan kerugian perusahaan. Berikut dibawah ini adalah patokan harga TBS (Tandan Buah Segar) produksi pekebun Kalimantan Barat pada keadaan tanaman umur 3 tahun sampai dengan 20 tahun tahun 2013. 

berikut :

untuk menghindari kerugian perusahaan inti melakukan upaya-upaya sebagai

a. Melakukan sortasi TBS terhadap TBS yang dibeli secara totalitas oleh PTP Nusantara XIII sebagai kemitraan sehingga buah mentah dan tidak sesuai tahun tanam diberlakukan pinalti, pemotongan atau dikembalikan. Dimana selama ini TBS yang masuk sebagai sampel hanya $10 \%$ yang disortasi sedangkan $90 \%$ lolos tidak disortasi padahal TBS yang dikirim tidak sesuai dengan kualitas dan perjanjian.

b. Melakukan replanting kebun plasma yang sudah renta dimana rendemen sudah tidak sampai $21,4 \%$ dengan pola satu managemen.

c. Pelaksanaan sosialisasi supaya petani mengerti tahun tanam muda dan tanaman renta rendemennya lebih rendah dan diharapkan petani tidak mencampur TBS saat pengiriman ke pabrik.

d. Pemerintah melakukan kebijakan subsidi pupuk kepada petani plasma sehingga petani dapat membeli pupuk dengan harga yang kompetitif.

Selain kontribusi Kebun plasma terhadap Perusahaan yakni Kebun Ngabang, tentunya tidak bisa kita lepaskan kontribusi Kebun inti yakni Kebun Ngabang terhadap kebun plasma. Adapun kontribusi yang diberikan adalah sebagai berikut :

a. Penyerapan tenaga kerja

b. Meningkatkan pendapatan petani

c. Akses jalan lebih lancar dan lebih cepat dari satu daerah ke daerah lain.

d. Perusahaan khususnya kebun Ngabang menyediakan $2 \%$ dari keuntungan

e. Perkebunan dapat dijadikan sarana edukasi

f. Mempelopori pembentukan dan pembinaan KUD (Koperasi Unit Desa) pada setiap masing-masing kelompok tani.

g. Memberikan pendapatan $5 \%$ dari hasil penjualan TBS untuk pengururs KUD

Namun demikian seiring waktu berjalan pola PIR yang ada dikebun Ngabang dinilai sudah tidak menguntungkan. Berdasarkan kriteria keberhasilan tolak ukur kemitraan yang ditunjukkan sekarang ini menunjukkan sudah tidak saling menguntungkan antara kebun plasma dan inti yang ada di Kebun Ngabang PT Perkebunan Nusantara XIII (persero). Hal ini bisa dilihat dari pertama, kondisi di kebun plasma produktivitas kebun turun, harga pokok produksi naik, kualitas TBS turun, stabilitas pasokan bahan baku dalam hal ini ketersedian TBS juga turun. Kedua, kepercayaan antara inti dan plasma turun yang disebabkan ada sebagian petani yang kreditnya macet sehingga membebani keuangan kebun Ngabang sebagai pejamin kredit selin itu pembinaan yang dilakukan dalam hal penyuluhan sudah tidak bisa diikuti petani. Ketiga, Pendapatan petani meningkat dengan adanya kebun plasma yang dimiliki, namun karena ada sebagian petani yang melakukan kecurangan dengan mencampur tananamn muda untuk mendapatkan harga jual TBS yang tinggi membuat kerugian Kebun Ngabang dari selisih harga yang ditetapkan.Keempat, kemitraan Kebun Ngabang sebagai inti dan masyarakat sekitar kebun sebagai plasma mengalami penurunan akibat kredit macet, tidak terpenuhi pasokan bahan baku sesuai standar mutu yang diharapkan oleh pabrik walaupun tingkat kesejahteraan masyarakat sudah jauh meningkat dibanding sebelum terbentuknya pola PIR ini. Namun demikian masih adanya nilai positif yang tetap terjaga dari pola kemitraan ini yakni pagar sosial masih kokoh artinya konflik sosial antara kebun inti dan masyarakat sekitar kebun hampir tidak pernah terjadi. Selain itu juga masih adanya ketergantungan antara pekebun, karyawan dan masyarakat sekitar perusahaan. 
Manajemen yang ada pada pola PIR sekarang ini dikebun Ngabang terdiri dari 2 bagian yakni Inti dan Plasma. Berdasarkan analisa commen size dengan kontribusi yang sudah tidak menguntungkan lagi maka perlua adanya evaluasi. Salah satu yang bisa diusahakan kedepan adalah dengan Pola manajemen satu atap. Dengan pola ini sudah tidak ada lagi dua manajemen yakni inti dan plasma namun menjadi satu. Semua kegiatan yang ada dikebun diberlakukan sama anatar inti dan plasma. Manajemen puncak juga turut langsung kebawah untuk mengontrol. Hal ini dilakukan untuk dapat meneken Harga Pokok sehingga bisa memberikan keuntung maksimal bagi perusahaan khusunya Kebun Ngabang Pt Perkebunan Nusantara XIII (Persero). Jikapun pola ini masih dinilai kurang menguntungkan maka bisa juga dilakukan dengan pemisahan manajamen inti dan plasma secara sendiri-sendiri. Sehingga masing-masing manajemen bertanggung jawab penuh terhadap produksi dan biaya-biaya yang dikeluarkan. Selama ini walapun pisah antara inti dan plasma namun tetap menjadi satu kesatuan yakni kebun Ngabang diharapkan kedepan bisa dipisahkan dan berdiri sendiri.

\section{KESIMPULAN DAN SARAN}

\section{Kesimpulan}

Berdasarkan hasil penelitian dan pembahasan maka dapat diambil kesimpulan sebagai berikut:

1. Kontribusi kebun plasma terhadap keuntungan Kebun Ngabang PT Nusantara XIII (Persero) dari rata-rata data 6 tahun terakhir bernilai negatip dengan persentase $161,91 \%$..

2. Kontribusi kebun plasma terhadap perusahaan yakni Kebun Ngabang PT Perkebunan Nusantara XIII (Persero) yang bersifat non finansial yakni keamanan aset kebun Ngabang tetap terjaga.

\section{Saran}

1. Sebaiknya dilakukan peremajaan atau replanting (Tanam ulang) untuk kebun plasma agar jangan sampai perusahaan khususnya kebun Ngabang mengalami kerugian karena masa produktif pohon kelapa sawit pada tahun 2013 sudah habis.

2. Petani kebun Plasma sebaiknya dilakukan pembinaan lebih lanjut agar dalam pengembangan areal tanamnya, petani memilih benih yang sudah bersertifikat dan melakukan pemupukan yang sesuai anjuran serta perusahaan harus melakukan pengawasan yang lebih ketat terhadap TBS yang dibeli oleh perusahaan.

3. Sebaiknya bisa dilakukan pemisahan antara manajemen kebun inti dan manajemen kebun plasma berdiri sendiri-sendiri.

\section{DAFTAR PUSTAKA}

Adiwiganda, etl. 1995. Potensi Produksi Setiap Lahan kelas. Makalah optimalisasi pengolahan kelapa sawit. Medan.

Breaver, etl. 1968. Economi. Harvard University : Amerika

Breda dan Hendriksen. 1992. Laporan Keuangan Perusahaan. Kanisius : Yogyakarta

Chariri dan Ghozali. 2007. Neraca Rugi Laba. Kanisius : Yogyakarta

Daim, Chamindun. 2003. Pengembangan kemitraan dan Dukungan Pendanaanya di bidang perkebunan.Makalah Pengantar Falsafah Sains Program Pasca Sarjana Institut Pertanian Bogor. Bogor. 
Dewai Kusumawardani, 2003.Efisiensi Ekonomi Realtif dan Analisis Pendapatan Usahatani Tembakau Berdasarkan System Penguasaan Lahan sawah di Kabupaten Temanggung.TesisMIESPUndipSemarang. Tidak dipublikasikan.

Feldman, Matan \& Arkady Libman. 2007. Crash Course in Accounting andFinancial Statemen Analysis, Second E dition. Hoboken, New Jersey:

Hanafi dan Halim, 2007. Analisis Laporan Keuangan, Sekolah Tinggi IImu Manajemen YKPN, Yogyakarta.

Humphrrey. M. Thomas. 1997. Algebraic Production Functions and Their uses Before Cobb-Douglas. Federal reserve Bank of Richmond Economic Quarterly Volume 83/I winter.

Ikatan Akutansi Indonesia. 2004. Ilmu Akutansi. LPEFEUI. Jakarta

Julianty, Prastowo. 2002. IImu Ekonomi dan terapannya. Kencana : Jakarta

J. Sarwono. 2006. Metode Penelitian Kuantitatif dan Kualitatif. Yogyakarta : Graha IImu.John Wiley \& Sons inc.

Keiso dan Weygandt. 2002. Laporan Keuangan Perusahaan. Swadaya : Jakarta

Lubis.1990. Pontensi Produksi Kelapa sawit Indonesia. Makalah Optimalisasi pengolahan kelapa sawit. Medan

Machmur. M.1995.Pengembangan Kemitraan Usaha Agribisnis. Departemen Pertanian Agribisnis. Jakarta : Badan Agribisnis.

Mubyartoet al. 1992. Tanah dan Tenaga Kerja Perkebunan Kajian Sosial Ekonomi. Aditya Media, Yogyakarta.

Nacrowi dan Usman. 2006. Pendekatan Populer dan Praktis Ekonometrika untuk Analisis Ekonomi dan Keuangan, LPFEUI, Jakarta.

Pardamean. Maruli. 2011. Sukses Membuka Kebun dan Pabrik Kelapa Sawit. Jakarta : Penebar Swadaya.

Siahaan, R. H.1995. Pengembangan dan Pembinaan Perkebunan Rakyat. Universitas Sisingamangaraja XII. Medan.

Siregar. 2006. Laporan Keuangan Perusahaan. PT. Raja Grafindo Persada, Jakarta

Sukirno S, 2005. Ekonomi Mikro. PT Raja Grafindo Persada, Jakarta.

T. Guritno. 1992. Kamus Ekonomi. Jakarta : Erlangga.

Toni Wijaya, 2009.Analisis Data Penelitian Menggunakan SPSS. Yogyakarta : Universitas Atmajaya Yogyakarta.

www.kamusbahasaindonesia.org.Kamus Besar Bahasa Indonesia Online. Downloader: 12 Februari 2012.

www.wikipedia.com.Pengertian Laba. Downloader : 13 Februari 2012. 